\title{
BURDEN OF TYPE 2 DIABETES FROM THE HEALTHCARE PAYER PERSPECTIVE IN SLOVENIA BREME SLADKORNE BOLEZNI TIPA 2 S STALIŠČA PLAČNIKA ZDRAVSTVENEGA VARSTVA V SLOVENIJI Tomaž Nerat ${ }^{1}$, Mitja Kos ${ }^{1}$
}

\author{
Prispelo: 2. 8. 2012 - Sprejeto: 17. 12. 2012
}

Original scientific article UDC 616.379:615.214

\begin{abstract}
Introduction: Diabetes prevalence and costs are rising on aglobal scale. Therefore, it is necessary to periodically conduct cost studies for assessing the healthcare burden impact. In Slovenia, the last type 2 diabetes cost assessment was conducted in 2006, not including all diabetes complication costs. The aim of this study was to revise, update and compare to previously published datadirect healthcare costs of type 2 diabetes in Slovenia with additional complications costs consideration.

Methods: The study was performed from the healthcare payer perspective using the bottom-up approach, was prevalence based and estimated direct medical costs.

Results: We estimated total yearly direct medical costs of type 2 diabetes in Slovenia to 99,120,419 euro with annual per capita costs of 834.70 euro. The highest cost shares were attributed to cardiovascular complication costs (21,683,919 euro), diabetes co-medication (20,977,269 euro) and diabetes treatment medication (18,505,015 euro). Highest yearly costs per complication (all cases, all occurrences) were estimated for dialysis I and III (9,162,635 euro), stroke first year costs (4,951,306 euro) and congestive heart failure first year costs (4,879,533 euro). Yearly per one patient, the complication costs were highest for kidney transplantation, followed by dialysis I and III (78,621.25 euro and 36,797.73 euro)

Conclusions: In comparison to the costs published in the literature before, our estimated total yearly direct medical costs were comparable, although annual per capita costs were assessed lower than elsewhere. Further, regarding the complication costs estimations, our assessed expenses were comparable to those published in other countries.
\end{abstract}

Key words: Diabetes Mellitus, type 2, cost of illness, public health, health expenditures, Slovenia, complications

Izvirni znanstveni članek UDK 616.379:615.214

\section{Izvleček}

Uvod: Prevalenca in stroški sladkorne bolezni v globalnem merilu naraščajo. Zato je treba redno izvajati študije stroškovnega bremena za oceno vpliva na zdravstvo. V Sloveniji je bila zadnja študija bremena sladkorne bolezni tipa 2 izvedena leta 2006 in ni upoštevala vseh stroškov diabetičnih zapletov. Cilj te raziskave je bil pregledati, posodobiti in primerjati s prej objavljenimi podatki neposredne medicinske stroške sladkorne bolezni tipa 2 v Sloveniji $z$ upoštevanjem dodatnih diabetičnih zapletov.

Metode: Študija je bila izvedena z vidika plačnika zdravstvenega varstva; uporabljen je bil pristop »bottom-up « $S$ prevalenčnim vidikom in ocenjeni so bili neposredni medicinski stroški.

Rezultati: Letne neposredne medicinske stroške sladkorne bolezni tipa 2 smo ocenili na 99, 120.419 evrov z 834,70 evra letnih stroškov na osebo. Najvišji delež je pripadal stroškom srčno-žilnih zapletov (21,683.919 evrov), stroškom sočasno uporabljenih zdravil (20,977.269 evrov) in stroškom antidiabetikov in inzulinov (18,505.015 evrov). Najvišji letni stroški za diabetični zaplet (vse ponovitve in vsi primeri) so bili ocenjeni za dializo I in III (9,162.635 evrov), prvo leto možganske kapi (4.951.306 evrov) in prvo leto srčnega popuščanja (4,879.533 evrov). Najdražji zaplet sladkorne bolezni (letno na posameznega bolnika) je bila transplantacija ledvic (78.621,25 evra), sledili sta dializa I in III (letno na osebo 36.797,73 evra). 
Zaključek: V primerjavi s prej objavljenimi podatki v literaturi so $v$ tej raziskavi objavljeni letni neposredni medicinski stroški primerljivi, čeprav so letni stroški na osebo ocenjeni nižje kot drugje. Prav tako so stroškovne ocene posameznih zapletov sladkorne bolezni primerljive s prej objavljenimi.

Ključne besede: sladkorna bolezen tipa 2, stroški bolezni, javno zdravje, izdatki za zdravje, Slovenija, zapleti

\section{INTRODUCTION}

According to the World Health Organisation, 285 million people are currently suffering from diabetes. Newer projections are predicting that the number of cases will rise to 439 million by2030 (1). Global costs for the treatment of diabetes in the year 2010 were estimated to 376 billion dollars and according to predictions they will rise to 490 billion dollars in the year 2030 (2). Consequently, diabetes prevalence in Europe is expected to rise from 10 to 15 million patients in 2006 to 60 million patients in 2025 (3). In Slovenia, the latest known number of patients with type 2 diabetes was 118,750 (also considered in the Slovenian national program for diabetes control), with the incidence of 4,000 to 5,000 new cases yearly (3, 4). A previously published study showed that in 2006 type 2 diabetes accounted for 36.8 million euro in direct medical healthcare costs in Slovenia (3). The estimated costs represented $2.05 \%$ of total planned public healthcare expenditures and were simulated by a decision tree model for 170,000 patients (officially known and unknown cases) that were supposed to be optimally treated, focusing mainly on cardiovascular and cerebrovascular diabetes complications $(3,5)$. Therefore, the estimated expenditures were assessed too low.

The aim of this study was to revise, update and compare to previously published data healthcare costs of type 2 diabetes in Slovenia with additional consideration of nephropathy, retinopathy, neuropathy, foot ulcer complication costs, depression treatment costs and medical technical devices costs.

\section{METHODS}

The study was performed from the healthcare payer perspective. Therefore, the following direct medical costs that are relevant from compulsory and complementary health insurance were included in the analysis: costs for primary health care, outpatient specialist care, acute inpatient care, emergency ambulance care, rehabilitation care and drugs. Estimation was made for 118,750 patients using the bottom-up approach and prevalence based. No group of patients was followed.
The included diabetes complications were nephropathy, retinopathy, neuropathy, foot ulcer complications, cardiovascular complications, cerebrovascular complications and hypoglycaemia (hypoglycaemia as an adverse effect of anti-hyperglycaemic therapy). The cost also included depression treatment and medical technical devices costs.

The costs for primary health care, outpatient specialist care and rehabilitation care were estimated on the feefor-service payments according to The Health Insurance Institute of Slovenia's classification of services, namely "The Green Book", its annual general agreements and the corresponding average healthcare prices for October 2011 (5-8). Acute inpatient care costs (from October 2011) were assessed using the Diagnosis Related Group (DRG) payment model, which is in use in Slovenia since $2003(9,5)$. To calculate the average DRG weight of an acute complication, all DRG codes related to that complication were adjusted to their occurrence rates.

The emergency ambulance care costs were evaluated through an expert panel. The service providers are paid by The Health Insurance Institute of Slovenia in flat, meaning that the cost details are not publicly available and consequently an expert opinion was needed. The costs were revalorised to October 2011.

Diabetes treatment drug costs and diabetes comedication costs were estimated on the drug prices thatare publicly available by the Agency for Medical Products and Medical Devices of the Republic of Slovenia (October 2011) and The Health Insurance Institute of Slovenia's outpatient drug dispense for the year 2008 database (1-3). The latter contains records of all drug dispenses in a particular year, including anonymous patient, health service provider and pharmacy data, anatomical therapeutic classification codes (ATC), drug working codes and expenses, therefore its use in cost studies is highly beneficial. Because of the medication pricing system in Slovenia, the database drug expenses were not revalorised and for simplicity we assumed that they were the same in 2011. The academic research on the database was conducted on behalf of the agreement between the Faculty of Pharmacy Ljubljana and The Health Insurance Institute of Slovenia. Because of anonymous 
patient data, privacy protection was assured. The database was not publicly available.

Medical technical devices costs were calculated through usage of The Health Insurance Institute of Slovenia's medical technical devices database, its business report for the year 2011 and device consumption literature data (1-3).

The overall direct medical healthcare costs were calculated by multiplying the quantities of the complication occurrences with obtained costs. The occurrence rate of an individual diabetes complication was assessed combining the Health Insurance Institute of Slovenia's published data and data published on Medline. The first year occurrence rates were assessed from incidence data, consequently the following year occurrence rates were assessed from prevalence with subtraction of incidence data.

Because the overall type 2 diabetes expenses were derived from complication and drug costs that depend on average healthcare prices for the given year, we concluded that the total cost calculation is valid for the year 2011, although type 2 diabetes prevalence data derives from the year 2007 and the DRG incidence rates from $2009(4,10)$.

For verification of obtained cost items and estimating external comparability, we compared our evaluated diabetes complication costs of dialysis, transplantation, amputation, myocardial infarction, stroke, hypoglycaemia and costs of drugs (blood glucose lowering) with previous published studies. The following search phrases (yielded over 10,000 articles) were used:

- (economic OR cost OR costs) AND ("renal disease" OR "renal replacement" OR dialysis OR "kidney transplantation")

- (economic OR cost OR costs) AND ("lower extremity amputation")

- (economic OR cost OR costs) AND (stroke OR infarction)

- (economic OR cost OR costs) AND (complications AND diabetes)

- (economic OR cost OR costs) AND hypoglycaemia

The relevant articles for this publication were selected using a three stage approach. In the first stage, we selected appropriate articles based on title keyword relevance, excluding the majority of obtained search results. In the second stage, the selected articles were then screened through their abstract relevance, resulting in 61 articles remaining. In the last, third stage, we selected articles that clearly described the structure of the costs estimations and were freely available or the abstract contained all needed information and the result was given per patient/per complication/per year (1-18).
Please refer to supplementary Table A and B with detailed descriptions of the relevance and validity of the data used and validity of assumptions.

\section{RESULTS}

\subsection{Yearly type 2 diabetes burden estimation from the payer perspective in Slovenia}

The total yearly direct medical costs of type 2 diabetes in Slovenia were estimated to be 99,120,419 euro, with an annual per capita cost of 834.70 euro. The largest cost components were cardiovascular complication costs $(21,683,919$ euro), diabetes co-medication costs $(20,977,269$ euro) and diabetes treatment drug costs $(18,505,015$ euro) $(6,8-11,1-3,47)$. The latter were followed by nephropathy costs $(13,032,321$ euro), which accounted for a significant cost share despite their low yearly complication occurrence count $(6,7,9,12,1-7)$. Also high were estimated costs for medical technical devices, which totalled 9,717,892 euro yearly (14-16). Cerebrovascular complications further accounted for a $7.10 \%$ cost share $(7,041,178$ euro), foot ulcer complications for a $5.15 \%$ share $(5,108,738$ euro) and neuropathy for a $1.06 \%$ cost share $(1,054,500$ euro) $(6$, 8-12, 36, 1-5, 53, 54). The lowest cost components were estimated for depression (712,560 euro), retinopathy $(670,694$ euro) and hypoglycaemia $(616,333$ euro) $(6$, $9,10,12,13,41,1-8)$.

Highest yearly costs per complication (all cases, all occurrences) were assessed for dialysis I (haemodialysis) and III (haemodiafiltration) following years costs $(9,162,635$ euro), which were followed by stroke first year costs $(4,951,306$ euro), congestive heart failure first year costs $(4,879,533$ euro), amputation costs $(4,249,724$ euro) and peripheral vascular disease following year costs $(3,475,348$ euro) $(6-11,35,37,38$, $42,45-47)$. Also significantly high were estimated yearly costs for congestive heart failure in following years $(3,273,440$ euro) and costs for myocardial infarction in following years $(2,877,831$ euro) $(6,9,11,47)$.

The detailed complication cost breakdown with corresponding sources is presented in Table 1 and in supplementary Table A and B.

\subsection{Yearly costs for a single type 2 diabetes complication occurrence}

Among nephropathy, the highest yearly cost for a single complication occurrence was estimated for kidney transplantation, followed by dialysis I and III $(78,621.25$ euro and $36,797.73$ euro) $(7,9,42)$. Jointly, 
both attributed for the significant nephropathy cost share. The transplantation following year costs totalled $3,304.42$ euro and yearly microalbumine screening costs 4.20 euro $(6,9,12,42-44)$.

Regarding the retinopathy estimations, we calculated only costs for argon laser treatment and yearly eye screening, which cost 26.90 euro and 10.74 euro respectively $(6,9)$.

Among neuropathy, a single case treatment costs 29.60 euro $(6,9,12,14)$.

The highest foot ulcer complications costs were attributed to amputation and gangrene treatment $(7,884.46$ euro and $3,160.68$ euro) and were followed by foot lesion occurrence treatment and the yearly foot screening costs (110.17 euro and 6.32 euro) $(6,9,10)$. The highest cardio or cerebrovascular complication payer burden was estimated for stroke occurrence $(6,895.97$ euro) and myocardial infarction occurrence $(5,290.66$ euro) (8-10). Stroke had a significantly higher DRG cost (3,794.20 euro vs. 2,813.91 euro) and higher rehabilitation costs $(1,876.21$ euro vs. $1,251.18$ euro) (8-10). We also estimated congestive heart failure costs $(3,727.68$ euro), peripheral vascular disease costs $(2,742.13$ euro) and angina pectoris occurrence expenses $(2,644.11$ euro) $(9,10)$. The following year payer burden was among the cardiovascular and cerebrovascular complications equal in general. All estimations ranged between 200 and 400 euro annually $(6,9,11)$.
The cost for a severe hypoglycaemia event that requires hospitalisation totals $3,160.68$ euro $(9,10)$.

In this publication, the payer burden of depression treatment among type 2 diabetes patients was also assessed. According to the literature, approximately $5 \%$ of diabetes type 2 patients are treated for depression. With the use of Slovenian drug dispense data, we estimated a yearly treatment cost to be 120 euro (12, 13).

Using The Health Insurance Institute of Slovenia's outpatient drug dispense database from the year 2008 , the type 2 diabetes treatment and co-medication drugs expenses were determined as noted further. Comedication was divided into three groups, starting with lipid modifying agents, which cost the payer annually 164.77 euro per patient, renin-angiotensin agents, which account for a yearly burden of 155.36 euro, and acetylsalicylic acid, which costs the payer 21.96 euro yearly per patient (11). Costs of blood glucose lowering drugs, which were taken by $56.542 \%$ of type 2 diabetes patients, accounted for a yearly burden of 116.37 euro per patient (11). Furthermore, insulins, which were taken by $18.126 \%$ of type 2 diabetes patients, totalled 496.70 euro per year per patient (11).

As noted in section 3.1, the detailed complication cost breakdown with corresponding sources is presented in Table 1 and in supplementary Table A and B . 
Table 1. Yearly type 2 diabetes burden estimation from the healthcare payer perspective in Slovenia. Tabela 1. Letna ocena bremena sladkorne bolezni tipa 2 s stališča plačnika zdravstvenega varstva v Sloveniji.

\begin{tabular}{|c|c|c|c|c|c|}
\hline $\begin{array}{l}\text { Cost component/ } \\
\text { Stroškovna postavka }\end{array}$ & $\begin{array}{c}\text { Component cost in } \\
\text { euro/ } \\
\text { Cena stroškovne } \\
\text { postavke v evrih }\end{array}$ & $\begin{array}{c}\text { Component } \\
\text { share*I } \\
\text { Delež postavke* }\end{array}$ & $\begin{array}{c}\text { Number of cases } \\
\text { per } 118,750 \\
\text { patients/ } \\
\text { Število primerov } \\
\text { na } 118750 \\
\text { bolnikov }\end{array}$ & $\begin{array}{l}\text { Cost of all cases } \\
\text { in euro/ } \\
\text { Stroški vseh } \\
\text { primerov v evrih }\end{array}$ & $\begin{array}{l}\text { Source }{ }^{\star \star /} \\
\operatorname{Vir}^{* *}\end{array}$ \\
\hline \multicolumn{6}{|c|}{ Nephropathy/ Nefropatija } \\
\hline $\begin{array}{c}\text { Dialysis I and III - first } \\
\text { year/ } \\
\text { Dializa I in III - prvo leto }\end{array}$ & $36,797.73$ & 0.051 & 61 & $2,244,662 €$ & $7,9,38,42$ \\
\hline $\begin{array}{c}\text { Dialysis I and III - } \\
\text { following years/ } \\
\text { Dializa I in III - nadaljnja } \\
\text { leta }\end{array}$ & $36,797.73$ & 0.210 & 249 & $9,162,635 €$ & $7,9,38,42$ \\
\hline $\begin{array}{l}\text { Transplantation - first } \\
\text { year/ } \\
\text { Transplantacija - prvo } \\
\text { leto }\end{array}$ & $78,621.25$ & 0.011 & 13 & $1,022,076 €$ & 9,39 \\
\hline $\begin{array}{l}\text { Transplantation - } \\
\text { following years/ } \\
\text { Transplantacija - } \\
\text { nadaljnja leta }\end{array}$ & $3,304.42$ & 0.090 & 107 & $353,573 €$ & $\begin{array}{c}12,38,42 \\
43,44\end{array}$ \\
\hline $\begin{array}{l}\text { Yearly microalbumine } \\
\text { screening/ } \\
\text { Presejalni test za } \\
\text { mikroalbuminurijo }\end{array}$ & 4.20 & 50.000 & 59,375 & $249,375 €$ & $6,9,40,41$ \\
\hline \multicolumn{6}{|c|}{ Retinopathy/ Retinopatija } \\
\hline $\begin{array}{c}\text { Argon laser treatment/ } \\
\text { Argon laser }\end{array}$ & 26.90 & 1.033 & 1,227 & $33,006 €$ & $6,9,51$ \\
\hline $\begin{array}{c}\text { Yearly eye screening/ } \\
\text { Slikanje očesnega ozadja }\end{array}$ & 29.60 & 30.000 & 35,625 & $1,054,500 €$ & $\begin{array}{c}6,9,41,52 \\
53,54\end{array}$ \\
\hline \multicolumn{6}{|c|}{ Neuropathy/ Nevropatija } \\
\hline $\begin{array}{l}\text { Neuropathy case } \\
\text { treatment/ } \\
\text { Zdravljenje primera } \\
\text { nevropatije }\end{array}$ & 29.60 & 30.000 & 35,625 & $1,054,615 €$ & $\begin{array}{c}6,9,12,14 \\
47\end{array}$ \\
\hline
\end{tabular}




\begin{tabular}{|c|c|c|c|c|c|}
\hline \multicolumn{6}{|c|}{ Foot ulcer complications/ Zapleti razjede na stopalu } \\
\hline $\begin{array}{c}\text { Foot lesion treatment/ } \\
\text { Zdravljenje rane na } \\
\text { stopalu }\end{array}$ & 110.17 & 0.750 & 891 & $98,161 €$ & $6,9,48$ \\
\hline $\begin{array}{l}\text { Gangrene treatment/ } \\
\text { Zdravljenje gangrene }\end{array}$ & $3,160.68$ & 0.103 & 122 & $385,603 €$ & $9,10,46,47$ \\
\hline $\begin{array}{l}\text { Amputation/ } \\
\text { Amputacija }\end{array}$ & $7,884.46$ & 0.454 & 539 & $4,249,724 €$ & $9,10,46,47$ \\
\hline $\begin{array}{l}\text { Yearly foot screening/ } \\
\text { Presejalni test za } \\
\text { diabetično nogo }\end{array}$ & 6.32 & 50.000 & 59,375 & $375,250 €$ & $\begin{array}{c}6,9,49,53 \\
54\end{array}$ \\
\hline \multicolumn{6}{|c|}{ Cardiovascular complications/ Kardiovaskularni zapleti } \\
\hline $\begin{array}{l}\text { Myocardial infarction - } \\
\text { first year/ } \\
\text { Miokardni infarkt - prvo } \\
\text { leto }\end{array}$ & $5,290.66$ & 0.305 & 362 & $1,915,219 €$ & $8,9,10,35$ \\
\hline $\begin{array}{l}\text { Myocardial infarction - } \\
\text { following years/ } \\
\text { Miokardni infarkt - } \\
\text { nadaljnja leta }\end{array}$ & 255.24 & 9.495 & 11,275 & $2,877,831 €$ & $6,9,11,47$ \\
\hline $\begin{array}{c}\text { Myocardial infarction - } \\
\text { fatal/ } \\
\text { Miokardni infarkt - } \\
\text { usoden }\end{array}$ & $2,172.24$ & 0.178 & 211 & $458,343 €$ & $9,10,35,36$ \\
\hline $\begin{array}{c}\text { Angina pectoris - first } \\
\text { year/ } \\
\begin{array}{c}\text { Angina pektoris - prvo } \\
\text { leto }\end{array}\end{array}$ & $2,644.11$ & 0.066 & 78 & $206,241 €$ & $9,10,35$ \\
\hline $\begin{array}{l}\text { Angina pectoris - } \\
\text { following years/ } \\
\text { Angina pectoris - } \\
\text { nadaljnja leta }\end{array}$ & 255.24 & 9.430 & 11,198 & $2,858,178 €$ & $6,9,11,47$ \\
\hline $\begin{array}{c}\text { Congestive heart failure } \\
\text { - first year/ } \\
\text { Srčno popuščanje - prvo } \\
\text { leto }\end{array}$ & $3,727.68$ & 1.102 & 1,309 & $4,879,533 €$ & $9,10,35$ \\
\hline $\begin{array}{l}\text { Congestive heart failure } \\
\text { - following years/ } \\
\text { Srčno popuščanje - } \\
\text { nadaljnja leta }\end{array}$ & 405.48 & 6.798 & 8,073 & $3,273,440 €$ & $6,9,11,47$ \\
\hline $\begin{array}{c}\text { Peripheral vascular } \\
\text { disease - first year/ } \\
\text { Periferne okvare obtočil - } \\
\text { prvo leto }\end{array}$ & $2,742.13$ & 0.534 & 634 & $1,738,510 €$ & $9,10,35$ \\
\hline $\begin{array}{c}\text { Peripheral vascular } \\
\text { disease - following years/ } \\
\text { Periferne okvare obtočil - } \\
\text { nadaljnja leta }\end{array}$ & 255.24 & 11.466 & 13,616 & $3,475,348 €$ & $6,9,11,37$ \\
\hline
\end{tabular}




\begin{tabular}{|c|c|c|c|c|c|}
\hline \multicolumn{6}{|c|}{ Cerebrovascular complications/ Cerebrovaskularni zapleti } \\
\hline $\begin{array}{c}\text { Stroke - first year/ } \\
\text { Možganska kap - prvo } \\
\text { leto }\end{array}$ & $6,895.97$ & 0.605 & 718 & $4,951,306 €$ & $8,9,10,45$ \\
\hline $\begin{array}{l}\text { Stroke - following years/ } \\
\text { Možganska kap - } \\
\text { nadaljnja leta }\end{array}$ & 264.88 & 5.995 & 7,119 & $1,885,681 €$ & $6,9,11,47$ \\
\hline $\begin{array}{c}\text { Stroke - fatal/ } \\
\text { Možganska kap - usodna }\end{array}$ & $2,172.24$ & 0.079 & 94 & $204,191 €$ & $9,10,36,45$ \\
\hline \multicolumn{6}{|c|}{ Depression treatment/ zdravljenje depresije } \\
\hline Depression/ Depresija & 120.00 & 5.000 & 5,938 & $712,560 €$ & $12,13,55,56$ \\
\hline \multicolumn{6}{|c|}{ Acute complications/ Akutni zapleti } \\
\hline $\begin{array}{l}\text { Hypoglycaemia/ } \\
\text { Hipoglikemija }\end{array}$ & $3,160.68$ & 0.164 & 195 & $616,333 €$ & $\begin{array}{l}4,9,10,11 \\
\quad 50,57\end{array}$ \\
\hline \multicolumn{6}{|c|}{ Medication/Zdravila } \\
\hline \multicolumn{6}{|c|}{ Co-medication/ Sočasno uporabljena zdravila } \\
\hline $\begin{array}{c}\text { Lipid modifying agents } \\
{[\mathrm{C} 10 \mathrm{AA}, \mathrm{C} 10 \mathrm{BA}] /} \\
\text { Zaviralci reduktaze HMG } \\
\text { CoA }\end{array}$ & 164.77 & 43.000 & 51,063 & $8,413,651 €$ & \\
\hline $\begin{array}{l}\text { Renin-angiotensin agents } \\
\text { [C09A, C09B, C09C]/ } \\
\text { Zdravila z delovanjem } \\
\text { na renin-angiotenzinski } \\
\text { sistem }\end{array}$ & 155.36 & 64.000 & 76,000 & $11,807,360 €$ & 11 \\
\hline $\begin{array}{c}\text { acetylsalicylic acid } \\
\text { [B01AC06]/ } \\
\text { acetilsalicilna kislina }\end{array}$ & 21.96 & 29.000 & 34,438 & $756,258 €$ & \\
\hline \multicolumn{6}{|c|}{ Diabetes treatment/ Antidiabetiki in insulini } \\
\hline $\begin{array}{l}\text { Blood glucose lowering } \\
\text { drugs/ Antidiabetiki }\end{array}$ & 116.37 & 56.542 & 67,144 & $7,813,547 €$ & \multirow[t]{2}{*}{4,11} \\
\hline Insulins/ Inzulini & 496.70 & 18.126 & 21,525 & $10,691,468 €$ & \\
\hline \multicolumn{6}{|c|}{ Medical technical devices/ Medicinsko tehnični pripomočki } \\
\hline $\begin{array}{c}\text { Devices for type } 2 \\
\text { diabetes patients on } \\
\text { insulin/ } \\
\text { Pripomočki za sladkorne } \\
\text { bolnike tipa } 2 \text { na insulinu }\end{array}$ & 451.47 & 18.126 & 21,525 & $9,717,892 €$ & $\begin{array}{c}4,11,14,15 \\
16\end{array}$ \\
\hline \multicolumn{4}{|c|}{$\begin{array}{c}\text { * - in \%, regarding to type } 2 \text { diabetes patients/ } v \% \text { glede na bolnike s sladkorno boleznijo } \\
\text { tipa } 2\end{array}$} & $\begin{array}{l}\text { Total yearly cost/ } \\
\text { Skupno letni stroški }\end{array}$ & \\
\hline \multicolumn{4}{|c|}{ 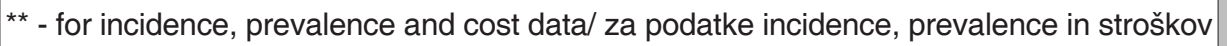 } & $99,120,419 €$ & \\
\hline
\end{tabular}




\section{DISCUSSION}

The calculated yearly direct medical costs of type 2 diabetes in Slovenia represent $4.18 \%$ of total planned national healthcare expenditures. The obtained result is greater than in France (3.4\%), the Netherlands $(1.6 \%)$ and the United Kingdom (2.5\%) but smaller than in Germany $(6.5 \%)$, the United States $(5.8 \%)$ and Italy $(6.6 \%)(1,2)$. This result confirms the substantial economic consequences of type 2 diabetes on healthcare expenditures. Furthermore, it publicises that Slovenia's diabetes payer burden is within the average of the burden in West European countries.

Although the healthcare expenditures are on average similar to other published studies, the officially known prevalence of type 2 diabetes (5.93\%), which is higher than in Belgium (3.3\%), France (2.2\%), Germany $(4.2 \%)$, Italy $(3.0 \%)$, the Netherlands $(1.7 \%)$, Spain $(3.9 \%)$, Sweden (3.6\%), the United Kingdom (2.0\%) and the United States (4.5\%), causes a lower per-patient cost in euros (834.70 euro) than in other West European countries (58.60). Consequently, we can assume that in Slovenia less than the average amount of money is spent on a type 2 diabetes patient, even though the payer burden is, as noted before, withinthe average of other established healthcare systems.

\subsection{Comparison of complications and drug costs to previous cost estimation studies}

As already pointed out, for verification of obtained cost items and evaluating external comparability, we compared our calculated type 2 diabetes costs with published estimations elsewhere. The findings are written below.

The costs for haemodialysis published before in the literature are on average similar to the costs estimated in the present article $(36,797.73$ euro). The estimations ranged from 29,786 euro in Spain (first estimation) to 61,000 euro in France and Germany $(18,19)$. The most similar costs to the ones in Slovenia were assessed for the United Kingdom (35,500 euro) and Spain (second estimation, 37,968 euro) $(17,18,20)$. Consequently, we can assume that our estimated cost for dialysis is in general similar to the one published before. We also cannot significantly alter our dialysis cost results, because they mainly consist of publicly announced payer reimbursements.

Regarding the assessment of transplantation costs, our estimation $(78,621.25$ euro) is higher than those in the Netherlands, France and Belgium (25,000-50,000 euro), Austria (51,000 euro) and Spain (38,313 euro)
$(18,21,20)$. Only in France were the costs estimated in 2010 higher (86,000 euro) (22). The published studies cover the hospitalisation and graft replacement procedure. Our expenditure estimation is based on published healthcare prices, which do not provide a price breakdown, so we cannot examine why our estimations are higher.

The expense payer burden comparison was also made for amputation, where our estimated costs $(7,884.46$ euro) were on average similar to the costs published previously (as in the case of dialysis). The lowest estimation established before was in Singapore $(5,188.33$ euro $)$ and the highest in Canada $(11,553.02$ euro) $(23,24)$. Most similar was the estimation for Australia, which totalled 9,450 euro (25). From the obtained comparable costs, we can assume that our amputation costs are assessed correctly.

Concerning the myocardial infarction occurrence, our estimated costs $(2,813.91$ euro only hospitalisation costs) were in terms of a wide-range assessed lower than in similar studies, although still comparable. The before published studies estimated infarction costs (only hospitalisation) to 3,502 euro in France, 3,387 euro in Germany, 3,064 in Italy, 3,870 euro in the Netherlands, 2,300 euro in Poland and 2,488 to 3,284 euro in Ireland (26-28). However, with the addition of ambulance and rehabilitation costs, our calculated costs $(5,290.66$ euro) were more comparable to before published data for France (5,916.45 euro), the Netherlands (5,599.30 euro) and to some extent less comparable to Italian costs $(7,450.22$ euro) (29). Nonetheless, we can assume that our estimations were made correctly. With reference to stroke episode costs, which we estimated to $3,794.20$ euro (hospitalisation costs), comparison was established for France (4,115 euro), Germany (3,980 euro), Italy (3,601 euro), Poland (3,434 euro), the Netherlands (4,548 euro), Argentina (2,993 euro) and Eastern Europe $(2,822)(26,30$, 31). Significantly higher were published estimations for Belgium (6,188 euro) and Western Europe (9,438 euro) $(32,31)$. The Belgian study encompassed costs for stroke and its associated disorders, which is the explanation for a higher payer burden. Regarding the higher Western Europe cost estimations, it has to be considered that the article also included studies with a longer (> 12 months) follow-up. This study also exposed the wide gap in healthcare prices between different geographic regions, as can be seen from low East European stroke costs. With consideration of ambulance and rehabilitation costs, our estimation $(6,895.97$ euro) did not differ significantly from previous published studies (Spain 5,435 euro, UK 7,393 euro, 
France 8,752 euro) (33), suggesting that our cost estimations are in general comparable to the costs published elsewhere.

Cost estimation comparison was made for hypoglycaemia as well. Our complication expenses were assessed for hospitalised severe cases and were totalled at 3,160.68 euro, which is similar to the costs for hospitalised cases in Germany (3,138 euro) and higher than the costs in United Kingdom (1,396 euro) and Spain (1,250 euro) (34).

Lastly, the drug cost comparison was prepared encompassing several European countries. The annual blood glucose lowering drug costs for Belgium amounted to 127 euro, for France 207 euro, Germany 119 euro, Italy 63 euro, the Netherlands 102 euro, Spain 61 euro, Sweden 41 euro and the United Kingdom 60 euro (58). Our drug dispense database based estimations amounted to 116.37 euro, which is similar to the other European countries.

\subsection{Study approach commentary}

The performed cost study was prevalence based, used the bottom-up approach and considered direct medical costs that are covered by the Slovenian healthcare payer.

In comparison to incidence based studies, our approach utilised a lesser amount of data, because there was no need for survival rate and the course of illness progression data. However, the cost calculation could be less accurate, as the prevalence based studies use mainly average case cost data instead of longitudinal illness development data.

Because diabetes is related to a significant number of complications, the bottom-up approach is a more valid method to estimate costs. With the usage of the topdown approach, the confounding variables and effect modification could lead to a higher overestimation of costs. With the usage of the bottom-up approach, this overestimation can be avoided.

In the present study, we estimated only direct medical costs, because the study was conducted from the Slovenian healthcare payer perspective. Therefore, a cost estimation from the societal perspective or business perspective was not needed, and the calculation of direct nonmedical or indirect costs could be avoided.

\subsection{Study limitations}

With regard to study limitations, we found no recent public available type 2 diabetes prevalence estimation for Slovenia than that from the year 2007 (used in the Slovenian national program for diabetes control) (4).
Because incorrectly estimated prevalence data could have a significant impact on the total cost calculation, the authors concluded to not predict any prevalence and therefore avoid a possible overestimation. Consequently, the assumption was made that the type 2 diabetes prevalence from 2007 is still valid for 2011. Secondly, the costs had to be calculated from multiple cost data sources. This limitation presented for the research a lesser issue because all expenses could be derived from Slovenian sources excluding foreign data. Also, a limitation was the usage of foreign literature data for the assessment of cardiovascular and cerebrovascular complications prevalence rates among type 2 diabetes patients. Nevertheless, the literature provided complications rates were utilised for the costs calculations with the assumption that they are similar to the ones occurring in Slovenia. In the future, it would be beneficial to have access to Slovenian data.

For the cost calculation of acute complications, we used the DRG payment model. The model does not distinguish between non-diabetes and diabetes patients, therefore our estimated cost could be underestimated because the average DRG weight is calculated from the average population. Also, there is a possibility that DRG codes contain incorrect ICD code records, which is a consequence of coding mistakes in praxis (2). In regard to hypoglycaemia, only costs for severe hospitalised cases were considered. Non severe cases can be treated by glucose ingestion, and the costs are minor in comparison to the hospitalisation costs. Furthermore, the non-hospitalised severe cases can be treated with glucose solution or glucagon injection by trained non-professionals or by professionals. Because the cost of such treatment is also low and we were unable to determine the proportion by which the treatment was performed, these costs were omitted. Regarding the cost estimation for medical technical devices, we calculated only costs for type 2 diabetes patients on insulins, because type 2 patients on blood glucose lowering drugs are by the health care payer in Slovenia not eligible for most of the devices, except in the case of test strips for optical reading (2). The latter represent a minor effecton the yearly per patient cost, therefore such estimation is appropriate.

\section{CONCLUSION}

We performed a direct medical costs study of type 2 diabetes in Slovenia and estimated the yearly costs to $99,120,419$ euro, with annual per patient costs of 834.70 euro in the year 2011. The result represents $4.18 \%$ 
of total planned public healthcare expenditures. The highest cost shares were attributed to cardiovascular complications, diabetes co-medication, diabetes treatment medication, nephropathy complications, medical technical devices and cerebrovascular complications. Consequently, all of them are a subject to be addressed when type 2 diabetes healthcare burden impact reduction is considered.

The type 2 diabetes cost estimation study was difficult to conduct for the reason that multiple complications or cost components had to be considered and for every complication reasonable and accurate cost data was needed, together with valid prevalence or incidence information. It was particularly difficult to distinguish between non type 2 diabetes patients and type 2 diabetes patients with regard to incidence and prevalence data. However, with the literature search we could discover the necessary information and reasonably estimate the shares. The latter therefore clearly indicates that the calculated expenses represent merely an estimation that should be carefully considered when discussing diabetes costs.

In the future, it would be beneficial to conduct a micro costing study to obtain more detailed data about the cost structure of diabetes treatment or diabetes complications.

\section{References}

1. Shaw JE, Sicree RA, Zimmet PZ. Global estimates of the prevalence of diabetes for 2010 and 2030. Diabetes Res Clin Pract 2010; 87: 4-14.

2. Zhang P, Zhang X, Brown J, Vistisen D, Sicree R, Shaw J, Nichols G. Global healthcare expenditure on diabetes for 2010 and 2030. Diabetes Res Clin Pract 2010; 87: 293-301.

3. Jelić J, Drinovec J, Mrhar A. Burden of type 2 diabetes. Farm vest 2006; 5: 316-324.

4. Nacionalni program za obvladovanje sladkorne bolezni, strategija razvoja 2010 - 2020, November 2009. Available October 15, 2011 from: http://www.mz.gov.si/fileadmin/ mz.gov.si/pageuploads/mz_dokumenti/zakonodaja/NP_ diabetes/Nacionalni_program_obvladovanja_sladkorne_bolezni_210410.pdf

5. Slovenian public healtcare expenditures plan for 2011. Available October 27, 2011 from: http://www.zzzs.si/zzzs/info/egradiva. nsf/o/E0455EFA06C92F42C1257826002F5012?OpenDocu ment

6. Enotni seznam zdravstvenih storitev in samoupravni sporazum o njegovi uporabi v svobodni menjavi dela (Greenbook). Ljubljana, 1982.

7. General agreement for the contract year 2010. Občasnik ZZZS. Available October 26, 2011 from: http://www.zzzs.si/ ZZZS/info/egradiva.nsf/0/89fd37d2ebe57302c1257711001b18 00/\$FILE/Ob\%C4\%8Dasnik\%20Akti\%20\&\%20navodila_1.\%20 del_03.05.2010.pdf

8. General agreement for the contract year 2010: design and financing of health services for natural health resorts. Občasnik ZZZS. Available October 30, 2011 from: http://www.zzzs.si/
ZZZS/info/egradiva.nsf/0/b2a6638bd0a4227cc1257711001b3c 31/\$FILE/Ob\%C4\%8Dasnik\%20Akti\%20\&\%20navodila_2.\%20 del_03.05.2010.pdf

9. Average healthcare prices, from 1.10.2011 on, ZZZS, Ljubljana, 2011. Available October 10, 2011 from: http://www.zzzs.si/zzzs/ pao/izvajalci.nsf/o/C796E9958FE5FC83C12579190011A716

10. Slovenian National Institute of Public Health, Sheet T13 (Number of acute healtcare events grouped by Diagnosis related groups - DRG in 2009). Available October 15, 2011 from: http://www. ivz.si/podatkovne_zbirke?pi=5\&_5_Filename=2086.xls\&_5_ Mediald=2086\&_5_AutoResize $=$ false \& $\mathrm{pl}=46-5.3$.

11. Data from The Health Insurance Institute of Slovenia outpatient drug dispense database from the year 2008.

12. Slovenian medicine costs on the day 14.10.2011. JAZMP Available October 15, 2011 from: http://www.jazmp.si/files/ farmakoekonomika/cene_20111014.xls

13. Slovenian National Institute of Public Health. Drug consume database from 2001 to 2010. Available October 11, 2011 from: http://www.zzzs.si/zzzs/internet/zzzs.nsf/o/ CEECE65B19F25E4FC1257552002BEC54

14. The Health Insurance Institute of Slovenia, Medical technical devices database. Available April 24, 2012 from: http://www.zzzs.si/zzzs/info/egradiva.nsf/0/dfdc914987 e44e2ac1257353003ec73a/\$FILE/SEZNAM\%20S\%20 \%C5\%AOIFRANTOM,MK,POSTOPKI,CS,\%201.3.2012.xls

15. The Health Insurance Institute of Slovenia business report 2011. Available April 24, 2012 from: http://www.zzzs.si/zzzs/ info/egradiva.nsf/0/59d2866474ebc834c12579e500286886 /\$FILE/Poslovno\%20poro\%C4\%8Dilo\%20ZZZS\%20za\%20 leto\%202011_19.4.2012.pdf

16. Yeaw J, Lee WC, Aagren M, Christensen T. Cost ofselfmonitoring of blood glucose in the United States among patients on an insulin regimen for diabetes. J Manag Care Pharm 2012; 18: 21-32.

17. U.S. Renal Data System, USRDS 2008 Annual Data Report: atlas of chronic kidney disease and end-stage renal disease in the United States. Bethesda: National Institutes of Health, National Institute of Diabetes and Digestive and Kidney Diseases, 2008.

18. (The data reported here have been supplied by the United States Renal Data System (USRDS). The interpretation and reporting of these data are the resposibility of the author(s) and in no way should be seen as an official policy or interpretation of the U.S. government.)

19. Postma MJ, de Zeeuw D. The economic benefits of preventing end-stage renal disease in patients with type 2 diabetes mellitus. Nephrol Dial Transplant 2009; 10: 2975-2983.

20. ParraMoncasi E, Arenas Jiménez MD, Alonso $M$ et al. Multicentre study of haemodialysis costs. Nefrologia 2011; 31: 299-307.

21. Villa G, Rodríguez-Carmona A, Fernández-Ortiz $L$ et al. Cost analysis of the Spanish renal replacement therapy programme. Nephrol Dial Transplant 2011; 26: 3709-3714.

22. Haller M, Gutjahr G, Kramar R, Harnoncourt F, Oberbauer R. Cost-effectiveness analysis of renal replacement therapy in Austria. Nephrol Dial Transplant 2011; 26: 2988-2995.

23. Blotière $P O$, Tuppin $P$, Weill $A$, Ricordeau $P$, Allemand $H$. The cost of dialysis and kidney transplantation in France in 2007, impact of an increase of peritoneal dialysis and transplantation. Nephrol Ther 2010; 6: 240-247.

24. Tan ML, Feng J, Gordois A, Wong ES. Lower extremity amputation prevention in Singapore: economic analysis of results. Simgapore Med J 2011; 52: 662-668.

25. Davis WA, Norman PE, Bruce DG, Davis TM. Predictors, consequences and costs of diabetes-related lower extremity 
amputation complicating type 2 diabetes: the fremantle diabetes study. Diabetologia 2006; 49: 2634-2641.

26. O'Brien JA, Patrick AR, Caro JJ. Cost of managing complications resulting from type 2 diabetes mellitus in Canada. BMC Health Serv Res 2003; $21: 7$.

27. Clarke PM, Glasziou P, Patel A, Chalmers J, Woodward M, Harrap SB, Salomon JA. Event rates, hospital utilization, and costs associated with major complications of diabetes: a multicountry comparative analysis. PLoS Med 2010; 7: e10000236.

28. Szmurło D, Schubert A, Kostrzewska K, Ryś P, SkrzekowskaBaran I. Economic analysis of the implementation of guidelines for type 2 diabetes control developed by Diabetes Poland: what increase in costs is justified by clinical results? Pol Arch Med Wewn 2011; 121: 345-350.

29. Heerey A, McGowan B, Ryan M, Barry M. Microcosting versus DRGs in the provision of cost estimates for use in pharmacoeconomic evaluation. Expert Rev Pharmacoecon Outcomes Res 2002; 2: 29-33.

30. Tiemann $O$. Variations in hospitalisation costs for acute myocardial infarction - a comparison across Europe. Health Econ 2008; 17: S33-S45.

31. Christensen MC, Previgliano I, Capparelli FJ, Lerman D, Lee WC, Wainsztein NA. Acute treatment costs of intracerebral hemorrhage and ischemic stroke in Argentina. Acta Neurol Scand 2009; 119: 246-253.

32. Luengo-Fernandez R, Gray AM, Rothwell PM. Costs of stroke using patient-level data: a critical review of the literature. Stroke 2009; 40: e18-e23.

33. Thijs V, Dewilde S, Putman K, Pince $\mathrm{H}$. Cost of hospitalization for cerebrovascular disorders in Belgium. Acta Neurol Belg; 2011; 111: 104-110.

34. Truelsen T, Ekman M, Boysen G. Cost of stroke in Europe. Eur J Neurol 2005; 12: 78-84.

35. Frier BM. The economic costs of hypoglycaemia. Br J Diabetes Vasc Dis 2011; 11: S10-S12.

36. Tenerz A, Lönnberg I, Berne C, Nilsson G, Leppert J. Myocardial infarction and prevalence of diabetes mellitus. Is increased casual blood glucose at admission a reliable criterion for the diagnosis of diabetes? Eur Heart J 2001; 22: 1102-1110.

37. Slovenian National Institute of Public Health, Sheet tb3 (Number of deaths grouped by International Classification of Diseases - ICD in 2009). Available October 12, 2011 from: http://www.ivz.si/Mp.aspx?ni=46\&pi=5\&_5_id=58\&_5_ Pagelndex=0\&_5_groupld=185\&_5_newsCategory=\&_5_ action $=$ ShowNewsFull\&pl=46-5.0.

38. Maple-Brown L, Cunningham J, Dunne K, Whitbread C, Howard $\mathrm{D}$, Weeramanthri $\mathrm{T}$, et al. Complicationsof diabetes in urban Indigenous Australians: the DRUID study. Diabetes Res Clin Pract 2008; 80: 455-462.

39. Buturović-Ponikar J, Adamlje T, Arnol M, Blanusa D, Ceglar Z, Cimerman-Steklasa $S$ et al. Hemodialysis in Slovenia - data from the Slovenian renal replacement therapy registry. Ther Apher Dial 2010; 14: A1-A15.

40. Kandus A, Arnol M, Kovac D. Forty years of renal transplantation in Slovenia. Ther Apher Dial 2010; 14: A1-A15.

41. Palmer AJ, Valentine WJ, Chen R, Mehin N, Gabriel S, Bregman $B$ et al. A health economic analysis of screening and optimal treatment of nephropathy in patients with type 2 diabetes and hypertension in the USA. Nephrol Dial Transplant 2008; 23; 1216-1223.

42. Sloan FA, Bethel MA, Lee PP, Brown DS, Feinglos MN. Adherence to guidelines and its effects on hospitalizations with complications of type 2 diabetes. Rev Diabet Stud 2004; 1: 29-38.
43. Buturović-Ponikvar J et al. Slovenian renal replacement therapy registry: 2006 annual report. Ljubljana: Slovenian Society of Nephrology, 2008.

44. Ponikvar R, Buturović-Ponikvar J. Dializno zdravljenje. Ljubljana: Klinični oddelek za nefrologijo, SPS Interna klinika, Klinični center Ljubljana, 2004.

45. Grego K, Arnol M, Bren AF, Kmetec A, Tomažič J, Kandus A. Basiliximab versus Daclizumab combined with triple immunosuppression in deceased donor renal Graft recipients. Transplant Proc 2007; 39: 3093-3097.

46. Kissela BM, Khoury J, Kleindorfer D, Woo D, Schneider A, Alwell $\mathrm{K}$, Miller $\mathrm{R}$, et al. Epidemiology of ischemic stroke in patients with diabetes: the greater Cincinnati/Northern Kentucky Stroke Study. Diabetes Care 2005; 28: 355-359.

47. G. Veninšek. Diabetes management in Celje general hospital. Zdrav Vest 2001; 70: 7-10.

48. Deshpande AD, Harris-Hayes M, Schootman M. Epidemiology of diabetes and diabetes-related complications. Phys Ther 2008; 88: 1254-1264.

49. V. Urbančič. Diabetic foot. Maribor: 3. Congress of family medicine, 2004.

50. Novo A, Jokić I. Medical audit of diabetes mellitus in primary care setting in Bosnia and Herzegovina. Croat Med J 2008; 49: 757-762.

51. Dejager S, Schweizer A. Minimizing the risk of hypoglycemia with vildagliptin: clinical experience, mechanistic basis, and importance in type 2 diabetes management. Diabetes Ther 2011; 2: 51-66.

52. Globočnik-Petrovič $M$, Urbančič $M$, Sevšek D. Smernice za presejanje in zdravljenje diabetične retinopatije. Zdrav Vestn 2010; 79: 17-I18.

53. Rosenberg JB, Friedman IB, Gurland JE. Compliance with screening guidelines for diabetic retinopathy in a large academic children's hospital in the Bronx. J Diabetes Complications 2011; 25: 222-226.

54. Singh P, Aronow WS, Mellana WM, Gutwein AH. Prevalence of appropriate management of diabetes mellitus in an academic general medicine clinic. Am J Ther 2010; 17: $42-45$.

55. Fera T, Bluml BM, Ellis WM, Schaller CW, Garrett DG. The diabetes ten city challenge: interim clinical and humanistic outcomes of a multisite community pharmacy diabetes care program. J Am Pharm Assoc 2008; 48: 181-190.

56. Anderson RJ, Freedland KE, Clouse RE, Lustman PJ. The prevalence of comorbid depression in adults with diabetes: a meta- analysis. Diabetes Care 2001; 24: 1069-1078.

57. Rubin RR, Ciechanowski P, Egede LE, Lin EH, Lustman PJ. Recognizing and treating depression in patients with diabetes. Curr Diab Rep 2004; 4: 119-125.

58. Ray JA, Valentine WJ, Secnik K, Oglesby AK, Cordony A, Gordois A, Davey P, et al. Review of the cost of diabetes complications in Australia, Canada, France, Germany, Italy and Spain. Curr Med Res Opin 2005; 21: 1617-1629.

59. Jönsson B; CODE-2 Advisory Board. Revealing the cost of Type II diabetes in Europe. Diabetologia 2002; 45: S5-S12.

60. American Diabetes Association. Economic costs of diabetes in the U.S. in 2007. Diabetes Care 2008; 31: 596-615.

61. Ballesta M, Carral F, Olveira G, Girón JA, Aguilar M. Economic cost associated with type II diabetes in Spanish patients. Eur J Health Econ 2006; 7: 270-275.

62. Nadathur S, Groom A. Codingand DRG relationships in stroke and transientischaemic attack (TIA). HIM J 2006; 35: 38-44.

63. The Health Insurance Institute of Slovenia. Compulsory health insurance rules. Available September 17, 2012 from: http://www. zzzs.si/zzzs/info/egradiva.nsf/0/5580D0555F5A1FEAC1256CF B003BB45C?OpenDocument 